\title{
Was Thomas Favent a Political Pamphleteer? Faction and Politics in Later Fourteenth-Century London ${ }^{1}$
}

\begin{abstract}
Thomas Favent's Historia has long been recognised as an important source for the turbulent middle years of Richard II's reign, in particular for its praise of the actions of the Lords Appellant in the Merciless Parliament of 1388. But why did Favent write the Historia and for whom was it written? In recent years the Historia has for the first time been subjected to detailed scrutiny and a case has made for regarding it as a political pamphlet written for a community of reformminded civil servants eager to celebrate the achievements of parliament. This study offers an alternative explanation. It seeks to place the Historia more squarely within the turbulent environment of London's factional politics. Favent's factional affiliations are easily discerned, but his motivations for writing the Historia were complex and multi-faceted. A new reading of this text suggests, in fact, that it was written not to perpetuate divisions within London, but to draw a line underneath them. The article highlights the use of textual representation to shape and ultimately control memories of political conflict.
\end{abstract}

Keywords: London; Thomas Favent; Nicholas Brembre; John of Northampton; Lords Appellant; Merciless Parliament; Richard II

Perhaps with the exception of the Modus Tenendi Parliamentum, the political tract known as Historia sive narracio de modo et forma mirabilis parliamento apud westmonasterium anno domini millesimo CCCLXXXVI is probably the most enigmatic of surviving 'unofficial' texts written about events to take place in the late medieval parliament. Unlike the Modus, we know who wrote the Historia, but this advances our knowledge of the manuscript very little, for the few scraps of evidence that shed light on who Thomas Favent was provide no real clues to establish when he wrote it, who came to read it and, most important of all, what its purpose was. Favent was a clerk, almost certainly a cleric in major orders, who was recorded as holding a benefice in the diocese of Salisbury from $1390 .^{2}$ Between 1391 and 1395 he was a customs officer in the port of London, assigned to collect the duties on tonnage and poundage. At least in these years we can be confident that Favent was based in London, though we have no knowledge of when he moved there from Shaftesbury (Dorset) where he probably grew up: his father had been mayor of the town in 1355. Other than his appointment as a customs official, there is no other known record of Favent's activities, though we might surmise from his authorship of the Historia that he supplemented the income from his benefice by taking on casual clerical work in the capital. He had a brother, Robert, who was returned as MP

\footnotetext{
${ }^{1}$ I would like to thank Caroline Barron for reading an earlier draft of this article, Linne Mooney for generously allowing me to draw on her palaeographical analysis of the Historia manuscript, and Kathleen Kennedy for her valuable communication with me on late medieval manuscript production. I take full responsibility for all interpretations in this discussion and for any weaknesses or errors therein.

${ }^{2}$ For the following biographical details see Clementine Oliver, 'New Light on the Life and Manuscripts of a Political Pamphleteer: Thomas Fovent', Historical Research 83 (2010), 60-68
} 
for Shaftesbury in the parliament of January $1390,{ }^{3}$ and a sister, Cecily, who became abbess of Shaftesbury abbey in 1398. He died in 1404. His text, the Historia, first came to attention when May McKisack published an edition in the Camden Society Miscellany of 1926. ${ }^{4}$ The original manuscript, Oxford, Bodleian Library, MS Bodley Rolls 9, was obtained by the Bodleian Library from an unknown donor in 1607. Since publication, the Historia has been used by historians primarily in a supporting role, to flesh out broader narratives of the reign of Richard II, and to demonstrate the popularity of the Appellants' attack on King Richard in 1388. In 2002 Andrew Galloway usefully published a translation of the text. ${ }^{5}$

Clementine Oliver's recent monograph is the first full-length study of Favent's writing and is a most welcome addition to the literature on Richard II's reign. ${ }^{6}$ Her study makes a case for regarding the Historia as a particularly important example of a growing culture of political pamphleteering in the last quarter of the fourteenth century. As such, it builds on the important article written in 1926 by T. F. Tout, on parliament and 'public opinion', ${ }^{7}$ and it draws on the more recent work of a number of literary scholars, most notably Kathryn Kerby-Fulton and Steven Justice, who have argued for the existence in London in Richard II's reign of a vibrant, reform-minded writing community within the 'civil service' and other members of the writing trades. ${ }^{8}$ It is a central tenet of Oliver's work that these civil servants were 'proto-parliamentarians', arch-advocates of parliament's role in guarding the kingdom's interests and bringing to account the misrule and corruption of the royal court. But Thomas Favent, Oliver argues, was no puppet of the Lords Appellant. His Historia resoundingly supports the attack launched by the Appellants against Richard's court, but it is the product of independent thinking, a text that captures the public mood of the time, or at least of the 'civil servants and government functionaries' amongst whom Oliver argues - in agreement with the earlier views of Tout and McKisack - that the tract was primarily circulated. Favent himself appears to have no special regard for the Appellants who are directly mentioned only a few times in his account, and even then without the unqualified enthusiasm one might expect of an author if he had been closely aligned with, or even directly commissioned by, the Appellant cause. Oliver's opinion is that the Historia presents an unaffiliated view of the crisis through the eyes of a well-informed and politically engaged bureaucrat.

${ }^{3}$ See J. S. Roskell, Linda Clark and Carole Rawcliffe, The Commons 1386-1421, The History of Parliament, 4 vols (Stroud, 1992), III, 113-14.

${ }^{4}$ Historia Mirabilis Parliamenti (1386), ed. May McKisack, Camden Miscellany, 14 (1926).

5 Andrew Galloway, 'Appendix', in: The Letter of the Law: Legal Practice and Literary

Production in Medieval England, ed. Emily Steiner and Candace Barrington (Ithaca and London, 2002), 231-52.

${ }^{6}$ Clemetine Oliver, Parliament and Political Pamphleteering in Fourteenth Century England (Woodbridge, 2010). Oliver has modified the traditional spelling of Favent to Fovent because this is how his name appears in the records. I have kept to the original spelling on the basis that Favent is the nearest approximation to the spelling of his name in the Historia.

${ }^{7}$ T. F. Tout, 'The English Parliament and Public Opinion, 1376-88', repr, in: Historical Studies of the English Parliament, ed. E. B. Fryde and Edward Miller (Cambridge, 1970), 299-317.

${ }^{8}$ K. Kerby-Fulton and Steven Justice, 'Reformist Intellectual Culture in the English and Irish Civil Service: the Modus Tenendi Parliamentum and its Literary Relations', Traditio 53 (1998), 149-202. 
Although, as we shall see, there are grounds to question some aspects of this new interpretation, on one point at least, there is little room for doubt. This is Oliver's contention that Favent was a Londoner, or at least a London resident, and observed the attack and subsequent purge of Richard II's household through the lens of the factional politics of the capital, and in particular as an enthusiastic supporter of John of Northampton, who was mayor of London between 1381 and 1383. The politics of London in the 1380s is incredibly difficult to disentangle and a number of different interpretations have appeared over the years. As far back as 1908 George Unwin characterised the conflict in terms of basic economic rivalry between the drapers of the city led by Northampton (i.e. the 'non-victuallers') and London's grocers, led by Nicholas Brembre (i.e. the 'victuallers'). ${ }^{9}$ In 1949, Ruth Bird saw the political fault-lines running in a different direction, arguing that they separated artisans and small traders on the one hand, and the wealthy wholesale traders - the 'merchant-capitalists' - on the other. ${ }^{10}$ In other words, according to Bird, it was a class conflict between the 'small' and great men of the city. Most recently, Pamela Nightingale has suggested that the conflict centred on the location of the wool staple and was, in essence, a clash between those merchants who favoured an overseas staple situated at either Bruges or Calais, because this provided them with a monopoly over the export market (i.e. the 'staplers', such as the grocers and fishmongers), and another group of merchants who preferred a domestic staple, because this stimulated the trade in luxury goods in London (e.g. the drapers, mercers and goldsmiths). ${ }^{11}$

However we choose to characterise the conflict - and it is not my purpose in this discussion to address the question directly - what is beyond dispute is that the internal squabbles of London's mercantile elite acquired far greater significance as a result of the alignment of the opposing parties with the political factions at court: John of Gaunt, the king's uncle, was patron to John of Northampton, whilst his arch enemy, Nicholas Brembre, had become the creature of Richard II and his favourites. When, in 1383, Nicholas Brembre successfully ousted Northampton from the mayoralty and subsequently had him tried and convicted using his connections at court, this created the conditions that would thrust London into the very epicentre of the political maelstrom that occurred in 1387-88 when Richard II's magnate opponents, the Lords Appellant, seized power and viciously turned on the king's favourites. ${ }^{12}$ Amongst their victims was Nicholas Brembre who had succeeded Northampton as mayor of London between 1383 and 1386 and who, in this time, had become even more closely associated with Richard II's unpopular court. It was shortly after this period of incredibly tense political drama that Thomas Favent decided to write the Historia. It is an exceptionally colourful and surprisingly personalised account of the tumultuous events between 1386 and 1388, with the greater part of the work devoted to a detailed description of the events of the Merciless Parliament of February 1388 in which the Appellants conducted their show trials of the king's favourites. Exactly what informed Favent's decision to write the Historia, and how it would have been received by its readers, are the underlying questions that underpin the following discussion.

\footnotetext{
${ }^{9}$ George Unwin, The Gilds and Companies of London (4 ${ }^{\text {th }}$ edn., London, 1963).

${ }^{10}$ Ruth Bird, The Turbulent London of Richard II (London, 1949).

${ }^{11}$ Pamela Nightingale, 'Capitalists, Crafts and Constitutional Change in Late FourteenthCentury London', Past and Present 124 (1989), 3-35.

${ }^{12}$ For background, see Nigel Saul, Richard II (New Haven and London, 1997), chapters 8 and 9.
} 


\section{Political Pamphleteering in the Later Fourteenth Century}

One of the difficulties in writing a book-length study on a text as oblique as the Historia is that much of the discussion is set to stand or fall on the judgements the author makes on the purpose of the writing and the motivation of its author. Clemetine Oliver makes a strong and well-argued case for regarding the Historia as a political pamphlet written primarily for circulation amongst a coterie of well-informed and intensely politicised civil servants and bureaucrats who had the highest regard for parliament because of the reformist, anti-corruption, agenda it stood for. But on a number of different levels these arguments can be challenged. In what follows I critique some areas of Oliver's interpretation, before moving on to consider some different perspectives and explanations. ${ }^{13}$ I offer these alternative suggestions in full acknowledgement of the great service Oliver's study performs in opening up debate about the engagement of the late medieval public sphere in political affairs, the politicisation of London's writing classes and the use and role of political tracts or pamphlets at times of crisis in government.

The first query relates to the question of the language Favent used to write the Historia. Latin was an odd choice for a document that was apparently intended to 'communicate ... a political argument to the public at large' 14 - even if this was, on the face of it, only the opinion of a more limited community of highly educated clerks. The argument that Latin was used to write the tract because its readership was made up of clerks and bureaucrats who could read Latin is, arguably, a circular one. But it is also tenuous, when one considers that this same readership was actively engaged in a writing culture dominated in the late fourteenth century by texts written in the English vernacular. ${ }^{15}$ But perhaps there are stronger reasons for thinking that Favent might have chosen French rather than English in compiling a pamphlet aimed at a readership made up of government clerks and bureaucrats. French was the language clerks would have associated most strongly with parliament, because it was used to compile the parliament rolls and to promulgate new statutes. French would not have been inappropriate for Favent's purposes, for it was used in the Anonimalle Chronicle to document the events of the Good Parliament of 1376, an account that Oliver herself characterises as one of the earliest examples of parliamentary pamphleteering. ${ }^{16}$ Moreover, the Anonimalle is widely believed to have been written by exactly the sort of individual who Favent is said to have aimed his Historia - the 'civil

${ }^{13}$ See also my review of her book in Nottingham Medieval Studies 55 (2011), 321-7. ${ }^{14}$ Oliver, Political Pamphleteering, p. 27.

15 A. I. Doyle and M. B. Parkes, 'The Production of Copies of the Canterbury Tales and the Confession Amantis in the Early Fifteenth Century', in: Medieval Scribes, Manuscripts and Libraries: Essays Presented to NR Ker, ed. M. B. Parkes and Andrew G. Watson (London, 1978), 163-210; A. Middleton, 'Chaucer's "New Men" and the Good of Literature in the Canterbury Tales', in: Literature and Society, ed. E. Said (Baltimore, 1980), 15-56.; K. Kerby-Fulton and Steven Justice, 'Langlandian Reading Circles and the Civil Service in London and Dublin, 1380-1427', in: New Medieval Literatures I, ed. Wendy Scase, Richard Copeland and David Lawton (Oxford, 1997), 5993; Linne R. Mooney, 'Chaucer's Scribe', Speculum 81 (2006), 97-138.

${ }^{16}$ Clementine Oliver, 'The First Political Pamphlet? The Unsolved Case of the Anonymous Account of the Good Parliament of 1376', Viator 38 (2007), 251-68. 
servant', John Scardeburgh, clerk of the Commons. ${ }^{17}$ In other examples of parliamentary 'reportage' from the period, notably the 'semi-official account of the Merciless Parliament incorporated into the Westminster Chronicle, French was also used. ${ }^{18}$ It was also used extensively in the late fourteenth century civic records, including many of the records produced for, and by, the government of the city of London. ${ }^{19}$

Undoubtedly, part of the problem lies in discerning what the Historia was written for: at different points Oliver characterizes it as a text written 'for recording history'; as an 'independent political tract'; and as a 'report intended for a readership hungry for news of parliament' ${ }^{20}$ One can accept that an author can have more than one motive in writing, but one cannot on the one hand argue that the use of Latin made the Historia a 'learned' or 'insider' text, and on the other, that it was 'written for the public'. ${ }^{21}$ The problems with terminology are compounded by the use of the word 'pamphlet' to describe Favent's work, and 'pamphleteering' to describe his activities. Oliver is careful to define pamphlet in its most limited sense, as a 'short book', but nevertheless throughout her study regards Favent as a forerunner of the political activists of the early modern era who had scurrilous texts circulated to a wide readership. It is debateable how far this comparison can be made. Before the advent of printing the cheapest, quickest and most effective way of disseminating political news or views as text was by having a 'broadsheet' displayed prominently in a public place, as the Lollards did in 1396 when they nailed the text of their Twelve Conclusions to the door of St Paul's cathedral. ${ }^{22}$ This text was written in the vernacular, as was the 'libel' written against Alexander Neville, archbishop of York, who was one of the appellees in the Merciless Parliament. ${ }^{23}$ It thus remains a matter of contention whether 'pamphleteering' was a realistic proposition before both printing and higher levels of literacy made the mass circulation of written texts an economical and a worthwhile undertaking. It is especially problematic to argue that texts written in Latin were used as the basis for pamphleteering.

${ }^{17}$ A. F. Pollard, 'Authorship and Value of the Anonimalle Chronicle', English Historical Review, 53 (1938), 577-605; and John Taylor, English Historical Literature in the Fourteenth Century (Oxford: Clarendon Press, 1987), 139-47 (esp. 198-205).

${ }^{18}$ The Westminster Chronicle 1381-1394, ed. L. C. Hector and Barbara F. Harvey (Oxford, 1982), 280-96.

${ }^{19}$ Lisa Jefferson, 'The Language and Vocabulary of the Fourteenth and Early FifteenthCentury Records of the Goldsmiths' Company', in: Multilingualism in Later Medieval Britain, ed. D. A. Trotter (Woodbridge, 2000), 175-211 (esp. 184); and Richard Britnell, 'Uses of French Language in Medieval English Towns', in: Language and Culture in Medieval Britain: The French of England c. 1100-c. 1500, ed. Jocelyn Wogan-Browne (York, 2009), 81-9.

${ }^{20}$ Oliver, Political Pamphleteering, 16; 63; and 149.

${ }^{21}$ Ibid., 17; and 147.

${ }^{22}$ Selections from English Wycliffite Writings, ed. Anne Hudson (Cambridge, 1978), 249. For more general discussion, see Wendy Scase, "Strange and Wonderful Bills": BillCasting and Political Discourse in Late Medieval England', in: New Medieval Literatures 2, ed. Rita Copeland, David Lawton and Wendy Scase (Oxford, 1998), 225-47.

${ }^{23}$ The text is Kew, The National Archives [all subsequent references to documentary sources are to The National Archives unless otherwise specified] C 49/9/22, printed by W. Illingworth, 'Copy of a Libel against Archbishop Neville, temp. Rich. II...', Archaeologia 16 (1812), 80-3. 
In fact, Favent himself makes clear what he thought he was writing for (and, indirectly, why he was using Latin) when he stated in the opening passage to the Historia that he 'should undertake to compose for posterity an account in formal written proceedings of certain extraordinary events [that] if every diligent reader would heed, he would have a mirror, in part, for more easily avoiding adversities, scandals, and the dangers and burning torments of death' (Historia, 1). ${ }^{24}$ Favent's declared aim was to write not to satisfy the whim of any one individual, but for a higher purpose: for posterity itself. Such a solemn undertaking required a suitably formalised style of writing; that is to say, the use of Latin, the language of record and authority (and also, of course, the language of the Church, where Favent had found his vocation). The Historia was thus a selfconscious act of remembrance or commemoration ('commemorated' is actually the word Favent uses to describe the Lords Appellant - Historia, 18). But its aim was also to preserve the memory of recent political upheavals for the benefit of the readers of the text. It therefore also served a didactic purpose. This was a common objective shared by many medieval historiographers. ${ }^{25}$ It suggests that the Historia is probably best and most straightforwardly characterised as a short history or chronicle of an especially turbulent period in London's history. ${ }^{26} \mathrm{We}$ should regard it as an important antecedent to the great proliferation of vernacular narrative texts produced by the lay citizens of London in the fifteenth century. ${ }^{27}$ Its chronicle format is a subject to which we shall return later.

Secondly, a large part of Oliver's argument rests on an untested assumption that the 'civil service' was highly politicized and strongly in favour of the reformist agenda pursued by the Appellants in 1388. Royal clerks in particular are said to have had 'a professional stake in the effectiveness of parliament' and especially the anti-corruption agenda that was pursued in $1388 .{ }^{28}$ But parliament was an irregular and occasional interruption in the professional lives of royal clerks whose real bread and butter lay in the employment they received in the main departments of state and the central law courts. As servants of the crown, often in receipt of royal annuities, it is worth asking whether such clerks would have so readily embraced the attack on the king and his supporters in $1388 .{ }^{29}$ It is true that some did: John Scarle, Geoffrey Martin and John Scarborough all played key roles in

${ }^{24}$ All references to Favent's text are to Galloway's translation (see footnote 5 above) where paragraphs are numbered consecutively.

${ }^{25}$ Note the comments of John of Salisbury: 'The examples of our ancestors, which are incitements and inducements to virtue, never would have encouraged and been heeded by everyone, unless, through devotion, care and diligence, writers triumphed over idleness and transmitted these things to posterity' - Historia Pontificalis (John of Salisbury, Policraticus or the Frivolities of Courtiers and the Footprints of Philosophers), ed. C. J. Nederman (Cambridge, 1900), Prologue to Book I, 3.

${ }^{26}$ For the most recent characterisation of the medieval chronicle, and how closely the Historia fits this mould, see Chris Given-Wilson, Chronicles: the Writing of History in Medieval England (London, 2004).

${ }^{27}$ Mary-Rose McLaren, The London Chronicles of the Fifteenth Century: A Revolution in English Writing (Cambridge, 2002).

${ }^{28}$ Oliver, Political Pamphleteering, 116.

${ }^{29}$ The example of Thomas Hoccleve, clerk of the privy seal between c. 1390-c. 1420, may be instructive on this matter. Hoccleve had every reason to resent the king and his government, because of the dilatoriness of the payment of his annuities. But he did not. Instead his service to the crown was a source of pride and self-esteem: see, especially, Ethan Knapp, 'Bureaucratic Identity and the Construction of the Self in Hoccleve's Formulary and La male regle', Speculum 74 (1999), 357-76, esp. 364. 
administering parliament on the Appellants' behalf and were materially rewarded as a result. Other beneficiaries included Robert Farrington, John Burton, Thomas Haxey, John Stacey and Richard Ronhale. ${ }^{30}$ But others did not. The research of Douglas Biggs indicates that the actions of the Appellants in 1388, far from stirring unbridled enthusiasm amongst civil servants for reform in government, instead created a wave of uncertainty and fear. ${ }^{31}$ Many clerks suffered at the hands of the Appellants. John Ripon (a chancery clerk) was imprisoned in the Tower of London where he languished until 1393. The king's secretary Richard Medford was similarly held in captivity until the mid1390s. Even minor chancery clerks, including Nicholas Southwell, Simon Shiringham, William Monkton, John FitzMartin, James Lustrake and John Holcote, were arrested and had their goods and benefices forfeited. Altogether fourteen clerks were imprisoned at the hands of the Appellants. Such was the level of insecurity generated by the Appellant seizure of power in 1388 than no fewer than seventy royal clerks sought an explicit acknowledgement of their economic status from the Appellant regime, by having their rights and benefices ratified by letters patent.

While these points go far in supporting the idea that the fortunes of many clerks were heavily dependent on the changing political landscape of the late 1380s, they also indicate that there was not a single, monolithic 'bureaucratic' perspective on whether the Merciless Parliament was a 'good' or 'bad' thing. They suggest, in fact, that opinion was sharply divided, and that Favent could not necessarily bank on the enthusiastic reception of his tract amongst all the clerks working in and around Westminster - if this is what he intended for it. In her recent work on the career of the chancery clerk John Scarle, Alison McHardy has suggested that there existed 'lethal rifts within chancery personnel' in the late 1380s, divisions that McHardy argues were driven in part by the attack on chancery that was implied in the questions Richard II put to his judges at Nottingham in $1387 .{ }^{32} \mathrm{It}$ is also a moot point whether the political fault lines within the royal bureaucracy, and more broadly within the writing circles in London, were determined by high political principles or by less edifying motivations such as the promise of employment, patronage and favour. Many of the clerks who helped the Appellants, like Scarle and Martin, had personal connections to the Lords Appellant or their supporters and were handsomely rewarded for their loyalty. Scarle counted amongst his many patrons the chancellor, Thomas Arundel and Henry Bolingbroke, earl of Derby. John Burton, Thomas Haxey, John Stacy, Edmund Stafford and Richard Ronhale also all had connections to Arundel. On the other hand, those clerks who suffered at the hands of the Appellants counted among their patrons some prominent members of the royal court. John Ripon, the clerk who was kept in prison until 1393, had strong connections with Robert de Vere, earl of Oxford (latterly Marquis of Dublin), as did John FitzMartin; William Monkton was closely associated with Alexander Neville, archbishop of York. The recruitment of clerks into the service of private patrons was such a commonplace in the fourteenth century that it hardly seems plausible that their political outlook was not in some way informed or

\footnotetext{
${ }^{30}$ Alison McHardy, 'John Scarle: Ambition and Politics in the Late Medieval Church', in: Image, Text and Church, 1380-1600: Essays for Margaret Aston, ed. Linda Clark, Maureen Jurkowski and Colin Richmond (Ontario, 2009), 77-8.

${ }^{31}$ For this and what follows, see Douglas Biggs, 'The Appellant and the Clerk: the Assault on Richard II's Friends in Government, 1387-9', in: The Reign of Richard II, ed. Gwilym Dodd (Stroud, 2000), 57-70.

${ }^{32}$ McHardy, 'John Scarle: Ambition and Politics', 82.
} 
influenced by these connections. ${ }^{33}$ I do not mean to suggest that clerks were incapable of thinking independently or acting on the basis of their own principles, but in a world that was driven by service and patronage, and by the formation of client-patron networks, it may be that personal association was just as much a factor in determining political convictions, as were idealism and ideology.

The third set of difficulties relates more broadly to the idea that Favent intended the Historia to be disseminated among a broad readership within the capital. Immediately, a measure of doubt is cast over this idea by virtue of the fact that only a single text survives that dates to the late fourteenth century (though the discovery by Caroline Barron of a second, fifteenth century text suggests that later copies were made). ${ }^{34}$ But there are other questions to ponder. If we accept that multiple copies were made and that Favent himself became somewhat of a cause célèbre among even a modest number of clerks and lawyers working in and around Westminster, it is surely pushing the boundaries of plausibility to think that the Historia did not also eventually come to the attention of the authorities, once the king regained power in 1389. Oliver herself describes the Historia as 'a passionate and vitriolic political tract' and states that Favent's authorial voice 'was born of "visceral hatred". 35 Are we then to suppose that the newly emboldened regime of Richard II in the early 1390s turned a blind eye to the Historia and its author in a spirit of reconciliation? Oliver argues that Favent did not suffer retribution for writing the Historia on the grounds that he was not specifically a 'partisan' of the Appellants - that he was a political 'pamphleteer', rather than an Appellant 'propagandist'. ${ }^{36}$ But it is unclear how or why Richard II or his supporters might have drawn such a distinction. Having formal ties with the Appellants was surely not the only qualification to expose supporters of what the Merciless Parliament had done to the possibility of retribution once the Appellants were gone. For those, like Favent, who were so enamoured of what had happened in 1388 that they positively glorified in the downfall of the king's favourites this point carries particular weight.

There is, here, a useful and obvious parallel to be made with Thomas Haxey, the audacious clerk who submitted a bill to the Commons in January 1397 complaining about the number of bishops and ladies present in the king's household. ${ }^{37}$ The bill was presented anonymously, but this did not keep Haxey safe from retribution. When Richard II discovered who had written the petition he was furious and immediately ordered Haxey's execution as a traitor (a decision that was later rescinded after the intervention of the archbishop of Canterbury). Haxey, like Favent, was no-one's stooge, but Richard was still set on making an example of him. It is true that Richard II was in no position to seek out and punish Favent in the aftermath of the Merciless Parliament, as he did Haxey in

${ }^{33}$ The key work is J. R. Maddicott, 'Law and Lordship: Royal Justices as Retainers in Thirteenth- and Fourteenth-Century England', Past and Present Supplement 4 (Oxford, 1978).

34 This second text is discussed in Oliver, 'New Light', 60-68.

${ }^{35}$ Oliver, Political Pamphleteering, 26.

${ }^{36}$ Ibid, 63-66.

${ }^{37}$ Parliament Rolls of Medieval England, ed. C. Given-Wilson et al (Leicester, 2005), CD-ROM version, parliament of January 1397, items 13-17 [hereafter cited as PROME]. For the circumstances of his bill, see Gwilym Dodd, 'Richard II and the Transformation of Parliament', in: Reign of Richard II, ed. Dodd, 71-84 (78-80). For background to Thomas Haxey, see A. K. McHardy, 'Haxey's Case, 1397: The Petition and Its Presenter Reconsidered', in: The Age of Richard II, ed. James L. Gillespie (Stroud, 1997), 93-114. 
January 1397. But one thing we know about Richard II is that he did not easily forgive or forget acts of disloyalty. One of the defining acts of Richard's last years was his decision to exclude fifty individuals from a general pardon or amnesty announced in the parliament of September $1397 .{ }^{38}$ It was a deliberate policy aimed to flush out anyone who had transgressed his authority in the past. In the end, over five hundred people came forward, the vast majority seeking exoneration for their actions during the period 138688. But Favent's name is not among them. ${ }^{39}$ This suggests that the Historia was never in fact widely circulated or known.

My fourth and final point relates to the depiction of parliament in the Historia. While it may be true that the Historia did not glorify in the achievements of the Lords Appellant, it does not necessarily follow that Favent's praise was instead reserved for parliament. A close reading of the Historia suggests in fact that Favent had no particular regard for the institution, beyond recognising its central role in providing a platform for the Appellants' assault on the royal court. He was not alone in this respect. Parliament features prominently in all the other main chronicles of Richard II's reign. This was not because these chroniclers were 'proto-parliamentarians' but because most chroniclers in this period were interested in 'high politics' - the politics of the court and of royal government - and high politics was conducted for the most part under Richard II in the context of parliament. Besides, if he had been a fan of parliament, would Favent not have given rather more credit to the Commons? MPs gave the institution its unique representative quality and in 1388 they were instrumental in supporting the Appellants' attack on the court. If Favent had wished to make a distinction between the actions of the Appellants on the one hand, and the actions of parliament on the other, one presumes that the Commons would feature more prominently in his account. But they do not. In the passages describing the opening scenes of this assembly, when the whole parliamentary community had come together to hear the chancellor's opening speech, Favent's description mentions only the presence of the king and lay and spiritual lords:

When therefore according to ancient parliament custom the laity on the left and the clergy on the right of the king had taken their seats, the chancellor standing in full view with his back to the king pronounced a certain speech, touching on the causes and matters of parliament, categorizing these according to tradition (Historia, 15). ${ }^{40}$

The absence of MPs is also implied earlier when Favent remarks that everyone of 'both estates' had gathered in the White Chamber at Westminster for the opening ceremony, but defines these estates merely as the 'lords and potentates of this realm' (Historia, 15). It is also noticeable that when, in the following paragraph, Favent refers to MPs he describes them as 'knights of the affinities', rather than by their more accurate description as 'knights of the shires' (Historia, 16). This was a cutting remark, for it suggested that the knights were in parliament to do their lords' bidding rather than to represent the interests of their constituencies or to pursue policies that served the interests of the

\footnotetext{
${ }^{38}$ PROME, parliament of September 1397, item 3. See Caroline M. Barron, 'The Tyranny of Richard II', Historical Research 41 (1968), 1-18 (6-9); The Chronicle of Thomas Usk, 1377-1421, ed. Chris Given-Wilson (Oxford, 1997), 24.

${ }^{39}$ I have consulted C 67/30 mm. 1-4, 19; and C 67/31 mm. 2, 4, 12-13.

40 The parliament roll notes that the chancellor's opening speech was delivered to 'full parliament' - i.e. comprising king, Lords and Commons (PROME, parliament of February 1388, item 1).
} 
kingdom as a whole. It was also heavily tinged with irony, given the Commons' agitation at this time to have liveries and retaining brought under control. ${ }^{41}$ Further doubt is cast on the Commons' dependability when, frustrated by delays in having Richard II's former tutor Sir Simon Burley brought to trial, Favent noted that the MPs

...requested that the king release them so that they might freely depart from parliament for their own business, and in future, when matters did not pertain to them, not to disturb them by giving the reason for such fatigue in future times that some misfortune had been fostered unexpectedly in the kingdom (Historia, 24)

The implication was that the Commons were indifferent to much of what had happened in parliament; their real concerns lay locally, with their own affairs, rather than with the affairs of state. This was not much of an advertisement for the effectiveness of the assembly, nor of the commitment of its representatives to political reform.

There is another factor that casts doubt on the idea that Favent held parliament in high esteem, for while it is true that supporters of John of Northampton, including Favent, will have derived enormous satisfaction from the outcome of the assembly, insofar as the executions of Nicholas Brembre and Robert Tresilian removed in one go the two individuals considered most responsible for Northampton's misfortunes, ${ }^{42}$ in other respects the Merciless Parliament will have left Northampton's supporters feeling rather less satisfied. The execution of Brembre did nothing to revive either the personal fortunes of Northampton, who remained banished from the City, or the controversial 'populist' policies he had pursued as mayor of London between 1381-3. ${ }^{43}$ Moreover, in a ruthlessly pragmatic approach to the city's government, the Appellants did not get rid of the mayor currently serving in office during the Merciless Parliament, Nicholas Exton, but chose instead to support him, even though Exton's 'royalist' credentials seemed hardly less pronounced than Brembre's. ${ }^{44}$ Most pertinently, Exton was every bit as implacable an enemy of Northampton as Brembre had been. He had been among those chosen to speak with the king in 1385 on behalf of the council requesting Northampton's execution. ${ }^{45}$ As mayor, Exton had deprived Northampton and his associates of their freedom in March 1387 and subsequently led opposition against moves to have Northampton pardoned in April of that year. ${ }^{46}$ At roughly the same time he had the 'Jubilee Book' burnt in an

${ }^{41}$ J. A. Tuck, 'The Cambridge Parliament, 1388', English Historical Review 84 (1969), 225-43 (esp. 234-5); Nigel Saul, 'The Commons and the Abolition of Badges', Parliamentary History 9 (1990), 302-15.

${ }^{42}$ Brembre brought about Northampton's trial in 1384 when he was mayor, and Tresilian, as chief justice of the king's bench, presided over the subsequent trial which resulted in Northampton's exile. For summaries of their careers, see Andrew Prescott, 'Brembre, Sir Nicholas (d. 1388)', and John L. Leland, 'Tresilian, Sir Robert (d. 1388)', Oxford Dictionary of National Biography (2004), online version [hereafter cited as ODNB].

${ }^{43}$ For Northampton's mayoralty, see Nightingale, 'Capitalists, Crafts and Constitutional Change', esp. 25-29.

${ }^{44}$ For his biography, see Paul Strohm, 'Exton, Nicholas (d. 1402)', ODNB.

${ }^{45}$ Calendar of Select Pleas and Memoranda of the City of London, a.d. 1381-1412, ed. A. H. Thomas (Cambridge, 1932), 54-7 [hereafter cited as $P \& M L]$.

${ }^{46}$ Calendar of Letter-Books of the City of London, Letter-Book H circa AD 1375-1399, ed. Reginald R. Sharpe (London, 1907), pp. 303-4, 305-7 [hereafter cited as Cal. LBH]. 
attempt to erase the civic reforms that Northampton had implemented in $1377 .{ }^{47}$ Exton had good personal reasons to block Northampton's rehabilitation, having lost his aldermanry and been banished from the city when Northampton had been mayor in August 1382. ${ }^{48}$ The common ground that existed between Brembre and Exton was no obstacle to Exton turning on Brembre in the Merciless Parliament - no doubt in order to safeguard his own position - but the confidence shown by the Appellants towards the mayor will have offered little comfort to the supporters of Northampton. From an institutional perspective, by involving Exton in the process of Brembre's trial and execution, parliament had effectively guaranteed the authority of an oligarchy whose attitude and approach to city government must have seemed to many to be little removed from the time when Brembre had been mayor in the period 1383-86.

Favent may not have had conviction in the innate importance of parliament, but he was a strong advocate of the divinely ordained nature of politics and government. For him God was the source of power and legitimacy, not the Appellants, nor even parliament. It is worth recalling that this was a tract written from the perspective of a clergyman. The conflict of 1386-88 is thus depicted not as the struggle between two rival political parties, but between good and evil, between God and the devil, incarnate in the form of the king's wicked advisors. Favent gives due recognition to the achievements of the Appellants, but he sees them above all as agents or instruments of God's will, and their actions as the manifestations of divine authority. Thus, at the point when the king and his favourites were plotting the downfall of the Appellants, Favent relates how '... our Commiserator and merciful Lord... not wishing to take vengeance abruptly but instead to take pity and tolerate still others .... inspired the hope and strength and understanding in the souls of the said three lords [i.e. Gloucester, Arundel and Warwick]' (Historia, 7). Later on, it was 'thanks to God' and also with 'angelic assistance' that the Appellants 'received the palm of victory' at the battle of Radcot Bridge (Historia, 11). For Favent, the root cause of the downfall of the king's advisors in 1388 was a selfishness that stemmed from their underlying moral and religious bankruptcy. Of the judges who had been banished to Ireland, Favent remarked: 'Behold men who did not place God before their gaze! You who read, examine how evil things, begun by evil beginnings, hardly are completed in any good conclusion. Wherefore, in all works, remember the end' (Historia, 26). The Historia acquires a didactic, almost homiletic tone, showing its readers the path to true salvation by highlighting the fate awaiting those who transgressed the will of God. It was a powerful rhetorical tool, for it furnished Favent with an almost unassailable authorial voice by intimating his ability to discern and convey the meaning and nature of God's purpose. In this sense, the Historia is more a religious text - a sermon, a political or politicised sermon - than a pamphlet. ${ }^{49}$

The distinctive moralistic note struck by the Historia is another reason to strongly associate the text, and Favent himself, with John of Northampton. Northampton's mayoralty between 1381-3 was marked by a vigorous campaign to clamp down on falsity, secrecy and public immorality, a campaign that targeted, amongst others, the

47 Cal. LBH, 303.

${ }^{48}$ Cal. LBH, 196-7, 204-5.

49 The Historia contains at least half a dozen biblical references. For discussion, see Andrew Galloway, 'The Literature of 1388 and the Politics of Pity in Gower's Confessio amantis', in: Letter of the Law, ed. Steiner and Barrington, 83-5, and also note 13 to his translation (on p. 242) which notes Favent's use of conventional sermonising techniques to begin his account of the Merciless Parliament. 
'false' beggars, fraudsters and prostitutes of the city. ${ }^{50}$ His implementation of what was tantamount to a moral crusade against London's underworld, and his well publicised concern for the city's poor, must have been important factors to explain Northampton's enormous popularity; but they may also explain why Thomas Favent was drawn so strongly to his cause. Northampton had taken decisive leadership in reforming the moral compass of the city. He had even taken a stand against the dissolute, corrupt practices of the lower clergy. ${ }^{51}$ Northampton himself seems to have been genuinely pious, perhaps driven by real religious zeal. ${ }^{52}$ Therefore, a man with Favent's ecclesiastical background need not necessarily have been directly in the pay of Northampton to feel great enthusiasm for the ex-mayor's time in office or a sense of outrage at his subsequent treatment at the hands of Nicholas Brembre. If Northampton's power had rested on a platform of moral reform and renewal, it was a natural corollary to think of his enemies as the enemies of all that was fair, right and just, and indeed, of God himself. For Favent, what had been at stake in the 1380s was not the political constitution or the role of parliament within it, but the very moral fibre of the kingdom itself and of its capital city. It was not the political ideology of the king's favourites, including Brembre, which filled Favent's heart with horror and disdain; it was his belief that these men had 'embraced the mammon on iniquity for themselves through much wickedness' (Historia, 2). Favent's purpose in writing the Historia was thus not to glorify in the achievements of parliament, but to note those things that he thought were worth remembering in order to serve as a moral lesson for future generations, showing how good always triumphs over evil. ${ }^{53}$ In this way, the Historia was written not as a tool of political faction, but as a means of uncovering truth in the service of God and the common good.

\section{New Contexts}

How, then, do we start to construct an alternative explanation for the Historia? It is important in the first place to acknowledge where Oliver's arguments withstand the weight of scrutiny. Oliver is almost certainly correct to dismiss the idea that the tract was a piece of political propaganda commissioned by the Lords Appellant to further their cause. This is an important revision to an historiographical tradition stretching back to the original thoughts of Tout. ${ }^{54}$ As I have noted elsewhere, there is a possible connection to be made between Favent and John Waltham, bishop of Salisbury, who had been sympathetic to the Appellant cause. ${ }^{55}$ I still think it possible that Waltham acted in some capacity as Favent's sponsor or patron. ${ }^{56}$ But Oliver is right to question whether any such

\footnotetext{
${ }^{50}$ Frank Rexworth, Deviance and Power in Late Medieval London (Cambridge, 2007), 141-87.

${ }^{51}$ Ibid., 150-1.

52 Admittedly this is difficult to judge, but see his will in Calendar of Wills Proved and Enrolled in the Court of Husting, London A.D. 1258-A.D. 1688, ed. Reginald R. Sharpe, 2 vols. (London, 1889-90), II, 333-5. I owe this suggestion to Caroline Barron.

${ }^{53}$ See Given-Wilson, Chronicles, 60-61.

54 Tout, 'Parliament and Public Opinion', 312.

${ }^{55}$ Gwilym Dodd, "Changing Perspectives: Parliament, Poetry and the "Civil Service" under Richard II and Henry IV', Parliamentary History 25 (2006), 299-322 (314, note $63)$.

${ }^{56}$ I therefore disagree with Oliver (Political Pamphleteering, 75, fn 48) that Favent condemned the papal translations (and therefore indirectly Waltham himself) which took place in 1388 in a 'biting passage' of the Historia: on the contrary, his tone was measured and matter-of-fact. He noted that canon law allowed the pope to claim the revenue from
} 
association necessarily made Favent an Appellant 'partisan' or that Waltham had direct involvement in the compilation of the Historia. The second perspective, in a sense, qualifies the first. It is Oliver's contention that the Historia is a text that should be located firmly in the factional politics of London in the late 1380s. She is most assuredly right on this point. The Historia is written with the authority of someone who claims to understand what is politically in the national interest, but the particular emphasis placed on the crimes and eventual fate of Nicholas Brembre and Robert Tresilian, and the trouble taken to exonerate John of Northampton of any wrongdoing, strongly suggest that the tract was aimed at a London audience. These two approaches provide a solid foundation from which to begin to re-contextualise Favent's work and understand his purpose in writing it.

We should start by expanding a point made earlier about the equivocation of the Appellants towards London's ruling oligarchy. The complex attitude of the Appellants to London's factional politics is best encapsulated in what was, for the purposes of this discussion, the single most important act of the Merciless Parliament: that is to say, the omission of John of Northampton and two of his closest associates from a pardon granted to all Londoners who were guilty of committing felonies and treasons between October 1382 and May 1388. The pardon had been granted at the request of the Commons. ${ }^{57}$ The exclusion of Northampton from its terms was unquestionably a decision taken by the Appellants, for they controlled parliament at this time. The decision highlighted their deep anxiety that Northampton's release would precipitate a renewed period conflict within the city. Almost certainly it indicated that the Appellants had done a deal with Nicholas Exton, in return for his co-operation over Brembre's conviction. The Appellants' equivocation over Northampton, indeed, their forthright refusal to countenance his rehabilitation, begs an obvious question: why should a supporter of Northampton write a narrative that glorified in their actions? To answer this, it is worth recalling that the petition presented by the Commons in 1388 was part of an ongoing campaign to secure Northampton from the terms of his punishment. ${ }^{58}$ In April 1387 Lord de la Zouche was reported to be urging the king to grant Northampton a charter of pardon. ${ }^{59}$ Before that, in May 1386, John of Gaunt - Northampton's loyal and trusted patron - had also (unsuccessfully) attempted to secure his release by appealing to Nicholas Brembre over dinner. ${ }^{60}$ Northampton had himself presented a petition to parliament asking for his release from Corfe castle - his request was probably submitted

these translations (an action described as 'construably a common right'), that parliament raised concerns about the resulting depletion of the kingdom's revenue, and that nothing happened because the clergy raised no objections ('their argument did not prevail in parliament since the clergy had not spoken against the pope's mandate'): Historia, 25. The strongest suggestion of a connection between Waltham and Favent, other than Favent's connection to the diocese of Salisbury, is the timing of their respective officeholding: Favent was appointed as a customs official in the port of London six months after Waltham became treasurer on 2 May 1391; Favent left this office in December 1395, just two months after Waltham had ceased acting as treasurer (he had died in September 1395); Calendar of Fine Rolls, 1391-99, 3, 163.

57 PROME, parliament of February 1388, item 37.

${ }^{58}$ See H. J. Mills, 'John of Northampton's Pardons', English Historical Review 52 (1937), 474-9.

${ }^{59}$ Cal. $L B H, 305$. Zouche was another victim of the Appellants.

${ }^{60} P \& M L, 109-113$. 
to the parliament that met in November $1384 .{ }^{61}$ The Historia might therefore, in part, have been conceived as a continuation of this campaign. It was driven, as all the other attempts had been, by an underlying sense of the injustice that Northampton had suffered at the hands of his powerful and influential enemies. It is likely, in 1388, that this sense of injustice turned to frustration as Northampton continued to endure his exile even though his enemies had been laid low.

Favent's aim was thus to establish a natural corollary between the fall of Northampton's enemies and the righteousness of his political redemption. Favent was aware, however, that Northampton was an immensely controversial figure, so he constructed his case by focussing on the deserving nature of the fates meted out to Nicholas Brembre and Robert Tresilian. Northampton is mentioned only towards the end of the tract, and only in the scene where his reputation is restored through the highly improbable confession of Brembre as he ascended the scaffold. Favent's treatment of Brembre and Tresilian, like that of the other appellees of the Merciless Parliament, is ferocious. There is no room for equivocation: they and their fellow appellees were the very personification of evil, as Favent put it, 'labouring in the devil's vineyard with indefatigable minds' (Historia, 6). Brembre, as mayor, is said to have presided over a regime that had oppressed the people of London and had resulted in the rivers running red with the blood of his hapless victims (Historia, 5); while Tresilian's pact with the devil was 'proven' when his shirt was removed to reveal the signs and names of demons (Historia, 19). ${ }^{62}$ The deserving nature of Northampton's cause is thus revealed by the unfathomable wickedness of his enemies. It also gains immeasurable strength because Brembre and Tresilian are shown to have acted against the interests of the king and the wider realm. The interconnectivity between London's politics and the politics of the court is what makes the Historia so powerful, and is a link that Favent exploits to the full. ${ }^{63}$ By casting Brembre and Tresilian as the common enemies of all who valued truth and justice he establishes a natural and logical affiliation between the Lords Appellant and Northampton. Thus, the Historia takes its place within a broad body of 'civic writing' to emerge in the 1380s in which, as Sheila Lindenbaum has argued, the London writers of this age of 'discursive "turbulence" learnt to use 'discursive conventions in markedly improvisatory and tactical ways ... to ensure that their writing seemed to belong to the public at large rather than to special interests'. ${ }^{64}$

${ }^{61}$ SC 8/129/6417. The petition is transcribed in Bird, Turbulent London, Appendix VI. 62 This story may not necessarily be fabricated. Don C. Skemer has shown that Favent's description of the 'astronomical characters' displayed about Brembre's body is verified by a similar account in the chronicle of John Northwood, though unlike Favent, Northwood regarded these symbols in more conventional terms, as textual amulets offering divine protection and grace: Binding Words: Textual Amulets in the Middle Ages (Pennsylvania, 2006), 194-99. That Favent should choose to highlight this aspect is especially interesting in light of the attempts to clamp down on Black Magic when Northampton had been mayor; see Rexroth, Deviance and Power, 151.

${ }^{63}$ As did the Appellants: see their letter to London dated November 1387: Knighton's Chronicle 1337-1396, ed. G. H. Martin (Oxford, 1995), 408-13.

${ }^{64}$ Sheila Lindenbaum, 'London Texts and Literate Practice', in: The Cambridge History of Medieval English Literature, ed. David Wallace (Cambridge, 1999), 284-309 (286-7). The 'politics of faction' and the choices this posed for the writers of the time is discussed by Paul Strohm, 'Politics and Poetics: Usk and Chaucer in the 1380s', in: Literary Practice and Social Change in Britain, 1380-1530, ed. Lee Patterson (Berkeley, 1990), 
If the Historia was neither a political pamphlet nor a news item, and yet still transmitted a powerful political message, what purpose did it serve? For whom was it written, and why? To answer this it is worth remarking firstly on the Historia's appearance, or at least the appearance of what appears to be the only surviving text to date from the late fourteenth century: MS Bodley Rolls 9 (see Figures 1 and 2). We have no way of knowing whether this is the original text or a later copy, but in either case it is significant that the manuscript is produced to an exceptionally high standard and, moreover, on its first folio, at the beginning of the second paragraph, there is an elaborate illumination of the letter ' $\mathrm{S}$ ', the decoration extending along both the left-hand and top margins in a beautiful sequence of pink and blue coloured foliage adorned with generous amounts of gold leaf. The trouble and expense taken to produce this manuscript strongly suggest that its purpose was not dissemination, but formal presentation. The illumination itself is top quality. The unusual formatting of the text as a roll is curious, since most chronicles at this time were written as codices. Exactly what significance should be attributed to this is unclear, unless we are to suppose that Favent (or his copyists) intended the text to be hung up for display or that by adopting this format it was hoped that it might exude greater authority by association with the record keeping practices of the royal bureaucracy. ${ }^{65}$ Many of London's civic records including, notably, the pleas and memoranda produced in the Guildhall and the city's customs records (which Favent would have been very familiar with after 1391) were produced in roll format, which may provide additional context. ${ }^{66}$ On the other hand, it is difficult to see how the other great attribute of the roll, that of portability, would have been of any benefit for a text like the Historia.

Two other points are worth noting. First, Favent did not identify himself in the Historia, but was named by another clerk, who also gave the text its title, in a separate annotation in the top margin. We should not read too much significance into Favent's apparent desire to preserve his anonymity: none of the forty-four London chronicles later produced in fifteenth century divulged the identity of its author. ${ }^{67}$ Anonymity was not necessarily the mark of sedition. It is, however, interesting that Favent should have been named by a third party: it suggests that at the time Bodley Rolls 9 was produced, his authorship of the Historia was widely known, or at least was in the public domain. Second, Favent made a point of explaining his reasons for writing the Historia and took particular care to justify his endeavours to his readers. There are several scenarios to explain these circumstances. The one that I favour is that the Historia was an unsolicited text written for, and presented to, a clearly defined readership (hence, the justification); that its appearance

83-112. See also Marion Turner, 'Conflict', in: Oxford Twenty-First Century Approaches to Literature: Middle English, ed. Paul Strohm (Oxford, 2007), 258-73.

${ }^{65}$ Pamela Robinson, 'The format of books: books, booklets and rolls', in: The Cambridge History of the Book in Britain, volume II, 1100-1400, ed. Nigel Morgan and Rodney M. Thomson (Cambridge, 2008), 41-54 (esp. 43-5); Don C. Skemer, 'From archives to the book trade: private statute rolls in England, 1285-1307', Journal of the Society of Archivists 16 (1995), 193-206 (esp. 198).

${ }^{66}$ For the plea and memoranda rolls, see Calendar of Select Pleas and Memoranda of the City of London, a.d. 1323-1364, ed. A. H. Thomas (Cambridge, 1926), vii-xi. For the customs records, see Paul Needham, 'The customs rolls as documents for the printedbook trade in England', in: The Cambridge History of the Book in Britain, volume III, 1400-1557, ed. Lotte Hellinga and J. B. Trapp (Cambridge, 1999), 148-63, (esp. 149-53) ${ }^{67}$ McLaren, London Chronicles, 25 and 47. 
was intended to impress and validate the views that it offered; and that the separate entry describing what the Historia was about (inaccurately) and who had written it, was a hasty act of secretarial orderliness by a clerk whose first priority was to make the document easily and straightforwardly identifiable. The heading to the Historia suggests, in particular, that the text was incorporated into a larger collection of miscellaneous documents where quick reference was needed for readers who would not have been immediately familiar with its contents.

In fact, thanks to the generous input into this discussion of Professor Linne Mooney, we are now in a much better position to understand the circumstances surrounding the production of the Historia. Professor Mooney's study of the palaeographical characteristics of the handwriting indicates that the Bodley Rolls 9 manuscript was not written by Favent himself, but by Richard Frampton, a free-lance, London-based scribe who would later come to prominence as a copyist of the Great Cowcher Books of the duchy of Lancaster. ${ }^{68}$ These were probably commissioned shortly after Henry IV came to power in 1399, to collate and record all the title-deeds of the duchy of Lancaster. ${ }^{69}$ Exactly what the relationship between Frampton and Favent was is impossible to tell. We cannot assume that they knew each other: if the Bodley Rolls 9 manuscript was not the original text, but a later copy, it is possible that the paths of both men did not cross at all. On the other hand, we cannot discount the possibility that Frampton and Favent were closely acquainted and that they directly collaborated to produce the Historia. If this was so - and assuming the manuscript was written shortly after the Merciless Parliament in 1388 - it would make Bodley Rolls 9 one of the earliest works Frampton is known to have written. It may also be significant that neither man was in regular employment. The relative obscurity of Thomas Favent is matched by the relative obscurity of Richard Frampton who, in spite of his obvious abilities, is not known to have secured tenure as a clerk in either the city or royal bureaucracies, nor even to have belonged to the Scriviner's Company of London. ${ }^{70}$ Frampton is known to have produced a book of statutes in c. 1391 which suggests that his work was already well regarded by this time and that he had connections with some sections of London's civic elite. ${ }^{71}$ This does not preclude the possibility that the Historia was formally commissioned: it may even add weight to the idea. But equally, there is a chance that the text was written for the same reasons that Thomas Usk wrote the Testament of Love, as an unsolicited gift intended to curry favour with London's oligarchy in the hope that lucrative office or employment

${ }^{68}$ M. B. Parkes, 'Richard Frampton: A Commercial Scribe c. 1390- c.1420', in: The Medieval Book and a Modern Collector: Essays in Honour of Toshiyuki Takamiya, ed. Takami Matsuda, Richard A. Linenthal and John Scahill (Cambridge and Tokyo, 2004), 113-24.

${ }^{69}$ R. Somerville, 'The Cowcher Books of the Duchy of Lancaster', English Historical Review 51 (1936), 598-615.

${ }^{70}$ Parkes, 'Richard Frampton, 123. 'Freelance' scribes like Frampton, along with government clerks, were probably the most prolific producers of literary texts in later medieval London, exceeding the output of those copyists who were formally licensed by the city authorities (i.e. the 'scriveners' and 'text-writers'). For a description of these categories, see Linne R. Mooney, 'Locating Scribal Activity in Late-Medieval London', in: Design and Distribution of Late Medieval Manuscripts in England, ed. Margaret Connolly and Linne R. Mooney (Woodbridge, 2008), 183-204.

${ }^{71}$ London Metropolitan Archives, COL/CS/01/008 (former ref.: CUST 8). 
would follow. ${ }^{72}$ The Historia was undoubtedly a good advertisement for Frampton's skill as a copyist and Favent's eloquence as an author. If this was the intention it seems to have worked, for the careers of both individuals subsequently improved: Favent shortly became a customs officer; and Frampton was employed as the official copyist for the duchy of Lancaster and, indeed, for Henry IV himself. The point I am making is that neither man is likely to have entertained the possibility of compiling the Historia had they thought their career prospects would suffer as a result. For this reason it seems unlikely that the text was conceived as an act of subversion or that it would have been regarded as especially contentious; it is more likely to have been written to please those people in authority who had the wherewithal and influence to make a positive difference to the livelihoods of the two men.

Favent's underlying purpose, then, was to put a positive gloss on the city's recent history. The Historia was written to appeal to London's rulers in the aftermath of the bloodletting of 1388. It offered a version of history that justified the actions taken by the city during the Merciless Parliament, but which also validated and legitimised the standing of those who now occupied positions of authority in civic government. We might regard it very much in the same light as the brief account of the Peasants' Revolt entered into the city's Letter Books in $1381 .{ }^{73}$ Like the Historia, this narrative deals with an especially awkward episode in the city's life, when the actions of many of its citizens will have been the source of discomfort and embarrassment. But the emphasis was on the loyalty of the civic oligarchy and the role its members played, and especially the mayor William Walworth, in crushing the rebellion. ${ }^{74}$ Favent's account was written to suggest that unity of purpose and collective solidarity prevailed within the city at the time of the Appellant rise to power. This was a serious distortion of history, for London was anything but unified at this time. Favent glosses over this. He acknowledges that proclamations were made in London in November 1387 forbidding its citizens from giving assistance to the earl of Arundel who was camped outside the city's walls with an army, but attributes these to the external influences of the 'false lords' surrounding the king (Historia, 8 ) $;{ }^{75}$ he acknowledges that London shut its gates to the Appellants in early December of the same year, but attributes this exclusively to the malign influence of Nicholas Brembre (Historia, 12); he implies that a broad swathe of London's citizenry were directly responsible for Brembre's execution by attributing his demise to the accusations made against him by the city's crafts, when in fact the crafts baulked the issue and left it to Exton and the alderman to seal the ex-mayor's fate (Historia, 18); and he fails to mention that these same London crafts, who presented complaints against Brembre in a set of coordinated petitions, were exclusively drawn from the non-victualling crafts, and that one of their main concerns was to reinstate Northampton's infamous policy of excluding victuallers from the city's office holding - these were crucial contexts that exposed the

\footnotetext{
${ }^{72}$ Marion Turner, 'Usk and the Goldsmiths', in: New Medieval Literatures 9, ed. David Lawton, Wendy Scase and Rita Copeland (Turnhout, 2007), 139-77 (esp. 164-7).

${ }^{73}$ Cal. LBH, 166; translated in Memorials of London and London Life in the XIIIth, XIVth and XVth Centuries, AD 1276-1419, ed. Henry Thomas Riley (London, 1868), 449-51.

${ }^{74}$ The divisions within London at the time of the Merciless Parliament are outlined in what follows. For the Peasants' Revolt, see Rodney Hilton, Bondmen Made Free: Medieval Peasant Movements and the English Rising of 1381 (London, 1973, repr. 1995), 189. Two aldermen, Walter Sibyl and John Horn, were later accused of opening the city's gates to the rebels: Bird, Turbulent London, 52-61.

75 The proclamation is noted in Knighton's Chronicle, 402.
} 
campaign against Brembre for what it truly was: a vindictive, factional, extra-judicial political lynching. ${ }^{76}$

It was in his treatment - or ignoring - of Nicholas Exton, however, that Favent indicated the true extent of his political agenda. To put it simply: where is Nicholas Exton in his account? Exton was mayor of London for the two years of the city's history addressed in the Historia (i.e. October 1386-October 1388) and was, as we have seen, a key player in the proceedings of the Merciless Parliament. Yet his name is mentioned not once. ${ }^{77}$ This is an extraordinary omission for a London-based writer whose purpose in writing the Historia - or so he claimed - was to set out the momentous events of these months lest they be forgotten by future generations. Clearly, there were some things, or people, who Favent hoped future generations would forget. For all his support of Northampton, and for all of the hostility with which he must surely have regarded Exton, as one of the leading opponents of Northampton, Favent evidently saw no advantage in writing an open polemic against a mayor whose position had been upheld by the Appellants. Exton was thus excised from Favent's version of events. In particular, what he does not acknowledge is that Exton had been closely allied with Nicholas Brembre in the closing months of 1387 in an attempt to secure the loyalty of London for Richard II. ${ }^{78}$ It was Exton, as mayor, who implemented the oath of loyalty sworn to the king on 5 October, an oath that also pointedly charged London's citizens to 'resist with all your power' the return of John of Northampton and his accomplices. ${ }^{79}$ According to Henry Knighton and the Westminster Chronicler, Exton had also responded enthusiastically to Richard's request for soldiers to resist the Appellants - Exton claimed he could raise no fewer than

76 The petitions were presented by the mercers (SC 8/20/997); cordwainers (SC 8/20/998); saddlers (SC 8/20/999); embroiderers (SC 8/20/1000); leather-sellers and whittawers (SC 8/21/1001B); founderers (SC 8/21/1002); pinners (SC 8/21/1003); painters (SC 8/21/1004); armourers (SC 8/21/1005); cutlers, bowyers, fletchers, spurriers and bladesmiths (SC 8/21/1006); drapers (SC 8/94/4664); goldsmiths (SC 8/198/9882); and tailors (C 49/10/3). The petitions have attracted more attention from literary scholars than historians because of the pioneering use of the English vernacular by the mercers to draft their petition, for which see Wendy Scase, Literature and Complaint in England 1272-1553 (Oxford, 2007), 67-77. Pamela Nightingale (A Medieval Mercantile Community: The Grocers' Company and the Politics and Trade of London 1000-1485 (New Haven and London, 1995), 312) suggests that the petitions were compiled in November 1387, but they are more likely to have been presented during the Merciless Parliament itself when the Appellants sought the cooperation of the Londoners in securing Brembre's conviction. The parliamentary provenance of these petitions is indicated in many of the petitions by their respective address clauses, which specifies the 'lords of parliament' along with the king, as the intended recipients of the request.

${ }^{77} \mathrm{He}$ is, however, alluded to in Favent's description of the arrival of the Appellant army before the gates of London in December 1387 where it is noted that the mayor (i.e. Exton) and citizens invited the lords and their retinues into the city 'that they might enjoy for their use and at their disposal all things in the city within reason and equity' (Historia, 12). Favent adds that the duke of Gloucester, on hearing this, ruefully commented 'Now I know truly that on-one can prevent liars from telling lies'. It seems likely that this reflected Favent's own scorn for a mayor whose retention of power in these difficult years had probably earned him a reputation for capriciousness and duplicity. ${ }_{78}$ As discussed in Nightingale, Medieval Mercantile Community, 309-11.

${ }^{79} \mathrm{Cal}$. $\mathrm{LBH}, 314-15$. This clause was not included in the copy sent to the king for his approval. 
50,000 armed men from the city. ${ }^{80}$ Knighton and Westminster also record the warm welcome the king and his entourage received when they entered the city early in November, at which point Exton 'came to meet them with a numberless company of citizens, all mounted and wearing the king's colours, that is to say, gowns of white and red'. ${ }^{81}$

The greatest distortion of Exton's position, however, occurs in Favent's treatment of the petitions presented by some of the London guilds in the Merciless Parliament. ${ }^{82}$ While it is true that the main purpose of these supplications was to discredit the record of Nicholas Brembre ${ }^{83}$ there was also another agenda in play that sought the downfall of Nicholas Exton. This is something that Favent completely ignores. In the Historia he merely comments that 'many of the crafts of the city of London [complained] about many injuries and extortions torturously committed ... by Nicholas Brembre' (Historia, 18). But Nicholas Exton's right to exercise his office at the time of the Merciless Parliament was the subject of a direct challenge simply by virtue of the demand, common to almost all thirteen surviving petitions, that the statute of 1382 forbidding victuallers from urban office-holding be reinstated. ${ }^{84}$ As a leading fishmonger of the city, Exton was undoubtedly the primary target. But there were other more direct forms of attack. In the petition of the mercers, the faults of governance during the mayoralty of Nicholas Brembre were said to have continued in the time of Exton who, it was alleged, lacked the 'counseille of trewe men'. ${ }^{85}$ At the end of their petition, the cordwainers of London added a specific complaint against Exton, stating that he was 'elected by Brembre and his accomplices contrary to the city's franchise and custom of free election' and that he had burnt a book called the Jubilee Book that contained all 'the good articles concerning the good government of the city', for which Exton, Brembre and their accomplices ought to be 'punished for accroaching to themselves royal power and for invalidating and destroying the good laws and ancient customs' of the city. ${ }^{86}$ The cutlers, bowyers, fletchers, spurriers and bladesmiths were rather more forthright when they asked in their petition that Exton should be 'removed from office' (soit discharge de son office) since he was forejudged in the Guildhall of London for having been unjustly elected by Brembre and his accomplices. ${ }^{87}$ When, at the end of parliament, the Appellants sanctioned legislation that permitted the complete freedom of both denizen and alien merchants to trade in the kingdom, notwithstanding the franchises enjoyed by London, ${ }^{88}$ the Westminster Chronicler was clear where the responsibility lay for this serious erosion of the city's liberties:

${ }^{80}$ Knighton's Chronicle, 407; Westminster Chronicle, 207.

${ }^{81}$ Knighton's Chronicle, 403; Westminster Chronicle, 207. .

${ }^{82}$ See above, footnote 76.

${ }^{83}$ For which, see Marion Turner, Chaucerian Conflict: Languages of Antagonism in Late Fourteenth-Century London (Oxford, 2007), 13-15, 25-28.

${ }^{84}$ Statutes of the Realm, 11 vols (London, 1810-28), II, 28-9. The petition prompting the legislation is in PROME, parliament of October 1382, item 55.

${ }^{85}$ SC 8/20/997, printed in John H. Fisher, Malcolm Richardson and Jane L. Fisher, An Anthology of Chancery English (Knoxville, Tn., 1984), no. 161.

${ }^{86}$ SC 8/20/998, printed in Rotuli Parliamentorum, 6 vols (London, 1767-77), III, 226-7.

${ }^{87}$ SC 8/21/1006.

${ }^{88}$ PROME, parliament of February 1388, Part 1 (Roll), item 29; Statutes of the Realm, II, 53-4. 
At the beginning of the parliament certain mercers, goldsmiths, drapers, and other restless elements in the city of London presented in the parliament bills of complaint against the fishmongers and the vintners, whom they described as victuallers, unfitted in their judgement to control a city so illustrious. These trouble-makers, with their wrong-headed new doctrines and their ill-natured behaviour, apply their efforts rather to the city's undoing than to letting it enjoy its liberties, as events show, for they petitioned that their mayor, Nicholas Exton, should be deposed and (in flagrant breach of the citizen's privileges and statutes) examined and have judgement passed upon him by a judge from outside. ${ }^{89}$

A reader of the Historia would have no inkling of the disfunctional state of London's government at the end of the 1380s, nor of the deeply opposed views of its citizens, as highlighted by the widely diverging accounts of Thomas Favent and the Westminster chronicler respectively.

For whose attention did Favent intend his Historia? Whereas previous scholars have regarded the text as a manifestation of the interest of London's civil service in the politics of the 1380s, as indicated already, I consider it more likely to have been aimed at the city's rulers. The fact that it was written in Latin need not deflect us from this view. Recent work on the private compilations of miscellaneous documents by London's citizens in the fourteenth century - otherwise known as 'custumals' - suggests that the urban elite from at least from the rank of alderman had a keen interest in documenting the history, customs and laws of their city as well as a higher than basic level of (Latin) literacy to indulge this interest. ${ }^{90}$ One of these custumals - London, British Library, MS Egerton 2885 - dates to the late fourteenth century (possibly 1395) and contains not only royal charters and lists of civic officials, but also a Latin summary of the Brut chronicle. Significantly, the manuscript has been identified as the compilation of an unknown merchant fishmonger. ${ }^{91}$ The Historia could easily, then, have been written with the city's oligarchy in mind, and possibly even for one of it mayors. Nicholas Exton, who remained in the mayor's office until October 1388, is one candidate. Favent was no supporter of Exton, but then the Historia was not written to celebrate Exton's achievements as mayor. The tract instead offers some pointed warnings about the folly of placing personal ambition above the common interests and unity of the city. By betraying Nicholas Brembre, Exton had shown himself to be every bit as fickle and unscrupulous in his political loyalties as the notorious under-sheriff of Middlesex, Thomas Usk, who was executed by the Appellants in $1388 .{ }^{92}$ For many of London's citizens, Exton must have appeared to be a man who would stop at nothing to preserve his own power and position within the city. Sure enough, in the Cambridge Parliament of September 1388, the council issued a notification prohibiting the defamation of Nicholas Exton after rumours had been circulating that he intended having London's liberties annulled and his old ally

${ }^{89}$ Westminster Chronicle, 337 (my emphasis).

${ }^{90}$ Debbie Cannon, 'London Pride: Citizenship and the Fourteenth-Century Custumals of the City of London', in: Learning and Literacy in Medieval England and Abroad, ed. Sarah Rees Jones (Turnhout, 2003), 179-98. See also, most recently, Malcolm Richardson, Middle-Class Writing in Late Medieval London (London, 2011), 74-80.

91 Cannon, 'London Pride', 192-3.

92 See Strohm, 'Politics and Poetics', esp. 85-90; and idem, 'The Textual Vicissitudes of Usk's "Appeal", in: idem, Hochon's Arrow: the Social Imagination of FourteenthCentury Texts (Princeton, 1992), 145-60. 
Robert Knolles installed as the city's military governor. ${ }^{93} \mathrm{He}$ was a dangerous and powerful man who needed to be reminded of the consequences of placing private interests above those of the commonalty. From Exton's point of view, however, the Historia offered more than a lecture in political moralising. In one sense it worked in his favour, for it ignored those parts of his record as mayor that highlighted his earlier alignment with Brembre and his opposition to the Lords Appellants. It also suggested the unwavering support of London under his mayoralty for the programme of reform that the Appellants had championed. Favent's uncompromising critique of Nicholas Brembre also served Exton's interests. It must have been difficult to ignore the callous and self-serving nature of Exton's betrayal of Brembre in the Merciless Parliament, but by emphasising the depravity and wickedness of Brembre's rule over the city, and his deplorable involvement in the politics of the court, the Historia made Brembre's demise more palatable to those sections of society who may have been shocked by the fickleness of their mayor's loyalties. The fact that the central role of Exton and his associates in sealing Brembre's fate was entirely passed over by Favent might have been the other side of the coin: Favent presents this not as the selfish act of a small number of oligarchs saving their own skins, but the concerted, collective action of the city.

Although the hypothesis has merit, on balance it seems unlikely: Exton's antipathy for Northampton was simply too ingrained for him and his allies to be receptive to a text that aligned itself with Northampton's interests and those elements in the city which had supported his policies. The Historia is more likely to have been written after Exton had left office, quite possibly during the mayoralty of his successor Nicholas Twyford (Oct. 1388-Oct. 1389). Twyford was a goldsmith and had a natural affinity with the political standpoint of the Historia. He belonged to the non-victualling party, had past associations with John of Northampton and had personally suffered at the hands of Nicholas Brembre. ${ }^{94} \mathrm{He}$ is far more likely to have responded to a text that upheld the condemnation of Brembre (the goldsmiths were one of the trades whose members had presented a petition against the former mayor in the Merciless Parliament) and which also sought the exoneration of Northampton. There is also some evidence to suggest that Twyford owed his election to the direct intervention of the Appellants who, by the Autumn of 1388, had lost confidence in the victuallers because their supply of loans had dried up. ${ }^{95}$ A text that underlined the unwavering support of London for the Appellants would clearly have appealed to Twyford. It would not have served his purpose, nor London's, to cast aspersions on the reputation and character of Twyford's predecessor, Nicholas Exton. To promote John of Northampton's cause, and the broader interests of the city, it was enough simply to castigate Nicholas Brembre. Twyford himself appears to have been a moderating influence on the politics of London. His priority was to reduce tension and rebuild political consensus within the city. This probably explains his decision to give the responsibility of electing members of the Common Council to the mayor and aldermen, thus neatly avoiding direct affiliation to either the supporters of Northampton, who favoured election by the guilds, or affiliation to the supporters of Brembre, who favoured election by the city's wards. ${ }^{96}$ The Historia was a product of this

93 Calendar of the Patent Rolls, 1385-89, 514.

${ }^{94}$ Cal. LBH, 225, fn 1; Bird, Turbulent London, 68-9. See also Paul Strohm, 'Twyford, Sir Nicholas (d. 1390/91)', ODNB.

${ }^{95}$ Nightingale, Medieval Mercantile Community, 321.

${ }^{96}$ Cal. LBH, 347; Nightingale, 'Capitalists, Crafts and Constitutional Change', 18-19, 32; Caroline Barron, London in the Middle Ages: Government and People, 1200-1500

(Oxford, 2004), 130-31. 
new atmosphere of restraint and reconciliation. It deliberately cast the divisions within the city in terms of personalities, rather than policies or factions. There was no open attack on the victuallers. Given what Favent could have said about Exton this point is of some significance. His decision to focus instead on Brembre was a clever one, for he understood that both the supporters and opponents of Northampton were complicit in Brembre's execution. The purpose of the Historia was not to prolong old struggles but to draw a line underneath them by suggesting unity of purpose and divine sanction behind the most extraordinary and unprecedented treatment of a London mayor by its citizens.

There is one other factor that lends support to the hypothesis that Nicholas Twyford was in some way connected to the Historia. This is Favent's remarkably lenient treatment of the notorious scrivener, Thomas Usk. If there was one figure who really deserved the opprobrium of a supporter of Northampton it was Usk. Usk had used the 'insider knowledge' he had gained as Northampton's clerk to compile an appeal that led directly to the conviction and banishment of his former master in 1384 . He was a notorious turncoat, and in some parts of the city was much vilified for his act of betrayal. ${ }^{97}$ Henry Knighton described him as 'a wicked and dishonest member of their [i.e. Brembre, Tresilian and the other the appellees of 1388] conspiracy'. ${ }^{98}$ Yet Favent's depiction of Usk and his demise is remarkably matter-of-fact, even sympathetic. He completely ignores Usk's earlier switching of sides and mentions only his appointment as undersheriff of Middlesex as the reason for his execution; even here, however, Favent exculpates Usk from responsibility by stating that he, and his accomplice John Blake, 'although of simple rank, had nonetheless ... been forced as accomplices into the aforestated treacheries' (Historia, 22). Such uncharacteristic generosity by Favent, after his scathing attacks on Brembre and Tresilian, may indicate a personal connection between the two men and perhaps even a grudging respect for Usk, whose literary work, the Testament of Love, may have been known to Favent . Alternatively, the explanation may lie in Caroline Baron's discovery that Usk was a salaried clerk to the Goldsmith's Company in the early 1380s. ${ }^{99}$ Could it be that Favent's treatment of Usk was indicative of the embarrassment that Usk had caused his erstwhile employees, by his shameful act of treachery against Northampton and the trades whose members supported him? Twyford may have been especially sensitive to Usk's disgrace, having possibly been the person responsible for introducing Usk to the goldsmiths in $1382 .{ }^{100}$ In writing an account of the political turmoil of the late 1380s for a mayor who was a prominent London goldsmith, perhaps Favent understood that the central role in these events played by an individual closely identified with the goldsmiths ${ }^{101}$ was better passed over and excused rather than flagged up and prominently condemned. Like his disregard for Nicholas Exton, Favent's treatment of Usk showed that his priority in writing the Historia was the simplification and sanitisation of the very complex and fickle world of London's politics.

${ }^{97}$ Henry Knighton records that after his execution, Usk's head was placed above the gate of Newgate 'because his family lived in that part of the city and was much hated':

Knighton's Chronicle, 501.

${ }^{98}$ Ibid, 481.

${ }^{99}$ Caroline Barron, 'Review of Lisa Jefferson, ed. Wardens' Accounts and Court Minute Books of the Goldsmiths' Mistery of London 1334-1446 (Woodbridge, 2003), Urban History 32 (2005), 173-5.

${ }^{100}$ Caroline Barron, 'New Light on Thomas Usk', The Chaucer Newsletter 25:2 (2004), 1.

${ }^{101}$ As described by Turner, 'Usk and the Goldsmiths', esp. 167-9. 
I should like to finish with two final considerations. First, John of Northampton was, finally, pardoned on 2 December $1390 .{ }^{102}$ The pardon was made at the specific request of the Commons in parliament, as a result of a common petition they presented to the assembly that met in November 1390. Although, at the time of parliament, the mayor of London was the goldsmith Adam Bamme, ${ }^{103}$ the common petition pointedly remarked that Bamme's predecessor, William Venour, a grocer, 'and all the aldermen of the said city testified by their oaths in the presence of our lord the king that the said John [of Northampton] was guilty of none of the aforesaid treasons and misprisions, nor had they ever known him to be anything other than good and loyal' ${ }^{104}$ While we cannot with any certainty attribute Northampton's changed fortunes to the Historia, there is nevertheless an unmistakeable resonance between the exculpation of his character in Favent's account and the declaration of his innocence in the parliament roll. Perhaps, after all, it was not Twyford but William Venour who was intended to benefit from Favent's account of the Merciless Parliament. Favent's description of the scene in which Brembre supposedly admitted his injustices to Northampton provided Venour with a perfect alibi with which to overturn a policy adopted for many years by the victualling trades, of flatly opposing the restoration of Northampton to the freedom of the city. London was beginning to heal its divisions. ${ }^{105}$ Factions were breaking down.

There may be an additional factor to support the idea that the Historia was aimed to please Venour rather than Twyford. This is the possibility that the text was written in part to pander to the interests and political tastes of John of Gaunt, duke of Lancaster. On 19 November 1389 Gaunt arrived back in England after over three year's absence in Spain trying to press his claim to the Castilian throne. On 13 December 1389 Gaunt was formally received into London by the mayor, William Venour, and the aldermen of the city. ${ }^{106}$ It is worth recalling that the two arch villains of the Historia from the point of view of Favent and many Londoners - Nicholas Brembre and Robert Tresilian - were also the two individuals who had done most to offend Gaunt before he left for Spain in July $1386 .{ }^{107}$ With the expectation that Gaunt would dominate the government of his young nephew, Richard II, on his return, the rulers of London and especially the mayor might well have appreciated the expedience of depicting their city's actions during his absence in the best possible light. Gaunt certainly had not forgotten what had happened in the 1380s. He appears still to have had John of Northampton's fate very much in mind. In

102 Cal. LBH, 359; Mills, 'Northampton's Pardons', 476-7.

${ }^{103}$ Although previously, in the 1380s, a close associate of John of Northampton, by the time of his mayoralty in 1390-1, Bamme had forged strong connections to the victuallers, marrying John Philpott's widow in 1392. His election could thus be seen as another attempt by the city to achieve cross-party consensus: see Turner, 'Usk and the Goldsmiths', 171-4.

${ }^{104}$ PROME, Parliament of November 1390, item 36.

105 Nightingale, Medieval Mercantile Community, 325.

106 Westminster Chronicler, 409.

${ }^{107}$ Brembre had audaciously stood in the way of Gaunt's efforts to secure Northampton's release in 1386, provoking Gaunt to write two letters to the mayor bitterly upbraiding him for his contumacy: $P \& M L, 109-11$. Tresilian was strongly implicated in the plot to have Gaunt murdered in February 1385, apparently pledging to "pass sentence upon him on whatever charges they brought against the duke': Thomas Walsingham, The St Albans Chronicle, volume 1, 1376-1394, ed. John Taylor, Wendy R. Childs and Leslie Watkiss (Oxford, 2003), 750-1. 
July 1390, in a meeting held at Leicester, he successfully petitioned the king to have Northampton released from captivity, though the latter was still not at this stage permitted to return to London. ${ }^{108}$ So long as Northampton continued to suffer misfortune as a result of his downfall in 1384, the citizens of London may still have felt vulnerable to the charge of collective culpability in his fate, so the Historia served a useful purpose by focussing all attention on the now deceased Brembre and the small group of corrupt courtiers with whom he had associated. We have no way of knowing whether Gaunt ever saw or heard about the Historia, but it is tempting to believe that Frampton's later connections with the duchy of Lancaster and with the Lancastrian regime, and perhaps even Favent's appointment as a customs official, was in part influenced by Gaunt's approval of their role in producing a text so favourable to his interests.

Secondly, sometime in 1391, possibly in the spring, all discussion of the city's recent history, insofar as it related to the 'diverse controversies' between Nicholas Brembre and John of Northampton, was outlawed. The ordinance, enacted by a new mayor of London Adam Bamme and the aldermen of the city, declared that:

no man, great or small, of whatsoever estate or condition he be, shall speak from henceforth, or agitate upon any of the opinions, as to either of them, the said Nicholas and John, or shall by sign, or in any other manner, show that such person is of the one opinion or the other. ${ }^{109}$

The measure was clearly designed to minimize the chances of further unrest. Perhaps it indicated that within the city's broader population divisions still ran deep, even if among the city's rulers a degree of reconciliation had been achieved. What the ordinance does suggest, however, is how Favent came to avoid any retribution once Richard II regained his authority in the mid-late 1390s. If the Historia had been written by Favent for the benefit of the city's rulers, as a way of coming to terms with the momentous events of the Merciless Parliament, by 1391 such a text appears to have fallen out of favour. For the Historia must surely be classified as precisely the sort of 'agitation' that Bamme's Ordinance aimed to prohibit, redolent as it was with the factional infighting that had crippled the city's government during the 1380s. Favent's purpose had thus been frustrated; the Historia had been overtaken by events and very quickly lost its relevance and value. But then, perhaps, this is what saved Favent. Like Thomas Usk, Favent had put himself into a position of extreme vulnerability by writing down an account that implicated him in the ideological turmoil of London's politics. But if the Historia had been withdrawn from public view almost as quickly as it had appeared, this will at least have offered Favent a measure of protection and anonymity that could never have extended to Usk once he so publicly nailed his colours to the mast by writing his Appeal. ${ }^{110}$

\section{Conclusion}

Was Favent a political pamphleteer? From what I have argued, I must conclude that he was not. Instead, the Historia demonstrates Favent's eloquence and creativity as a

\footnotetext{
${ }^{108}$ Westminster Chronicler, 442-4; Calendar of the Patent Rolls, 1388-92, 297.

${ }^{109}$ Cal. LBH, 365; Memorials of London, ed. Riley, 526-7.

${ }^{110}$ Paul Strohm, Hochon's Arrow: the Social Imagination of Fourteenth-Century Texts (Princeton, 1992), (chapter 7: 'The Textual Vicissitudes of Usk's "Appeal"'), 158; Turner, 'Usk and the Goldsmiths', 174-5.
} 
chronicler, his shrewdness as a political lobbyist and, possibly, his business acumen as a self-publicist. There is nothing obvious in the text of the Historia to suggest that Favent's work had been directly commissioned, though he clearly wrote to appeal to those sections of London's society that welcomed the death of Nicholas Brembre and that supported John of Northampton's rehabilitation. It may also have been written with an eye to the return to politics of John of Gaunt after the latter's absence abroad. On the other hand, I have argued that the tract was also written partly to generate memories that underpinned a new era of peace and stability in London and which also reflected positively on the city's recent past. To this end, I have suggested that the Historia was far less the tool of factional city politics than previously thought, a view that is informed as much by what Favent did not write about, as much as what he included. Favent chose his subject-matter carefully to appeal to broad-based sympathies. This reflected the changed political environment in the aftermath of the Merciless Parliament and the general desire of London's citizens to see a measure of consensus restored to the city's government. It could be that the Historia was written specifically to appeal to these more moderate influences. Favent appears to write out of a sense of personal conviction, but we cannot discount the possibility that he also had less principled motives for penning the Historia. It could have been equally (and simultaneously) the work of a business-minded clerk, making a pitch to secure better employment prospects for himself. In this regard, it may not be a coincidence that Favent appointment as a customs collector occurred shortly after the time when the Historia is most likely to have been written. We should avoid categorising the Historia too rigidly. I have loosely described the tract as a historical narrative or a short chronicle, but in its skilful and sophisticated assertion of textual authority, its surefooted navigation through London's perilous and complex political landscape, its sensitivity to the political dispositions of its readership and the possibility that the text was written for personal advancement the Historia has as much in common with the work of the famous London poets of the day - Chaucer, Gower and Usk - as it does with the prominent chroniclers of the same period - Walsingham, Knighton and the monk of Westminster. Favent's Historia thus usefully and instructively straddles both literary and historical academic disciplines. 